Roberto Gerhardt roberto@gerhardtcomunica.com.br Francisco Providência correio@fprovidencia.com Helena Barbosa helenab@ua.pt University of Aveiro
Blucher Design Proceedings Dezembro de 2014, Número 5, Volume 1

\title{
Portuguese museums and the new possibilities for design museography
}

This text focuses on the criteria to be used for the selection of Portuguese museums to be visited for the purpose of a museographic survey. The data will be collected to support research undertaken within the Doctoral Programme in Design, which is now in its initial phase. The ultimate objective will be to create a form of museographic practice in the area of design for the Portuguese Design Interpretation Centre, a project that is currently in progress at the ID+ Research Institute for Design, Media and Culture at the University of Aveiro.

In Portugal, the Portuguese Museum Network (RPM) (2000- ), consisting of 137 museums and palaces, supports various museological activities and as such serves as a guide for the present study. However, according to researcher José Mendes (2013) from the University of Coimbra, there are actually around 700 museological units in Portugal today. Thus, in order to achieve maximum representativity in this context, it was decided to use two sets of selection criteria: the first involving museums that were awarded prizes by the Portuguese Association of Museology (1965- ) during the last decade; the second including different thematic museums from the Portuguese Museum Network in order to ensure heterogeneity. For the survey itself, an exploratory qualitative method will be used to gather pertinent information relating to museography, architecture, mediation and interaction with the public. The information will be obtained by visiting the sites and for each one filling out a form that focuses in more depth on particular themes.

This article aims to present the criteria used in the selection of these museums, chosen to contribute to our understanding of the uniqueness of Portuguese museographic culture and therefore enabling the definition of a new territory of knowledge about museology in Portugal.

keywords museums, museography, heritage, Portugal, design

\section{Introduction}

The concept of the "museum" has developed over time in accordance with changes in the epistemological and museographic context. Thus, there have been different approaches to exhibition theory and practice, tied to the broad notion of heritage, and also new ways of enumerating and describing different collections in accordance with the epistemology underpinning each one'

Derrik de Kerckhove (1998), author of "Connected Intelligence", describes some situations and behaviours of contemporary society: 
"Now that our revolutions have become more technological than political, what do museums say about us, and how should they say it? As search systems manifesting the concerns that give meaning to living cultures, museums are relatively coherent representations of the value of hierarchies; and in their changing nature we can find well defined reflections of our evolving psychology" (1998: 175).

In the light of this museological development, this paper seeks to define criteria for the conceptual analysis of the different types of thematic museums in Portugal through their exhibitive discourse. It is hoped that the results of this analysis will credit the information that will be deployed in the research that is under way.

\section{The "museum" territory in Portugal}

One of the consequences of the European expansion in the $15^{\text {th }}$ century was the appearance of the first botanical gardens in Europe. The contact with exotic plants and animals had generated an interest in studying them, as occurred with the Portuguese Garcia da Orta (1500-1568), who travelled to India in the $16^{\text {th }}$ century and devoted himself to the study of the therapeutic properties of plants. His book "Colloquies on the Simples and Drugs of India" was published in Goa in 1563.

In the $16^{\text {th }}$ and $17^{\text {th }}$ centuries (Baroque period), curiosity cabinets appeared, ${ }^{2}$ the predecessors of art museums. These collections were made up of animal remains (bones, shells, feathers, skins), instruments of worship, tools from other civilizations etc, which brought material evidence of strange new worlds to European society. They disappeared in the $18^{\text {th }}$ and $19^{\text {th }}$ centuries with the appearance of ethnology and ethnography museums and new taxonomically organized exhibitions known as Natural History Museums. The latter brought together not only animal species but also plants, minerals and fossils, sometimes identifying the coherence of the geographic and landscape unit, or associated to gardens, aquariums and zoos where living organisms were displayed.

This revolution in mentalities which occurred in the second half of the $18^{\text {th }}$ century was marked by great advances in science, particularly in the field of medicine. Portugal was eager to participate in the scientific and cultural movement of the Enlightenment, which swept through Europe at this time. As a source of useful knowledge and economic resources, natural history was central to this movement, and it was in this context that the Royal Natural History Museum and Botanical Garden of Ajuda was created in 1768 (becoming Lisbon Botanical Gardens in 1878) ${ }^{3}$. The University of Coimbra botanical garden was created in 1772 upon the initiative of the Marquis of Pombal.

"The museum as an institution - the Temple of the Muses - dates back to Classical antiquity, though it entered a new era in the $18^{\text {th }}$ century with the creation of some public museums that went on to become famous" (Mendes, 2013: 31).

After this brief historical contextualization about the origin of museums, let us move forward to the end of the $2 \mathrm{O}^{\text {th }}$ century and the creation of the Living Science Centres.

\footnotetext{
${ }^{2}$ As a consequence of its voyages and discoveries, Portugal assumed a central mediating role the intellectual debate caused by a view of the world in constant change (Kraus \& Pereira, 2008) 3 See University of Lisbon (2010)
} 
This is a network of science museums overseen by the National Agency for Scientific and Technological Culture (created in 1996) to promote scientific and technological culture in Portuguese society, especially amongst young people. These are interactive spaces for the divulgation of science and technology, and function as platforms of regional development in the scientific, cultural and economic spheres. They offer an interactive experience through the use of autonomous devices - scientific demonstrators - conceived according to the same principles of experimental physics underpinning the machines that the Marquis of Pombal acquired for the University of Coimbra during the public education reforms of the $18^{\text {th }}$ century.

It was in this context that the RPM appeared, a structure dependent upon the Portuguese Museum Institute, whose initial task was to create and execute technical and financial programmes to support the improvement of museums and promotion of training schemes. It is by definition an autonomous body consisting of the various museums integrated into it.

"The aims of the Portuguese Museum Network are: the valuing and improvement of national museums; institutional cooperation and liaison between museums; the decentralization of resources; the planning and rationalization of public investment in museums; the dissemination of information about museums; the promotion of rigour and professionalism in museological practice and museographic techniques; the fostering of links between museums." (IMC, 2013).

At present the RPM 4 is overseen by the General Directorate for the Cultural Heritage (DGCP), and the 137 museums that form part of it are very diverse, with regard to their supervisory bodies, collections, spaces, educational activities, community relation models and management systems.

In recent decades, there has been a considerable interest in museology, leading to the appearance of several new museums in Portugal.

"Though the data provided do not always coincide, if we adopt the criteria used by ICOM (the International Museums Council), which defines the museum very broadly to include zoos, botanical gardens and aquariums, there are probably around 700 museological units in the country at present (September 2003)." (Mendes, 2013: 31-32)

These new museums are not only in the traditional domains of art, archaeology and history, but also in many others ranging from science and technology to ethnography and anthropology, including an unlimited number of themes related to the most diverse human activities. Museums have gradually been categorized epistemologically.

The Portuguese Museological Association (APOM) plays a significant role in this scenario. This is "a private non-profitmaking association based in Lisbon, which operates in the area of museology, heritage protection and similar matters" (CM-Oeiras, 2013). Its main aim is to group museological institutions and professionals in accordance with the criteria established by ICOM, promoting knowledge of museology and the scientific and technical domains that inform it, and highlighting the importance of the role played by museums and the museological profession in each community and amongst peoples and cultures (APOM, s.d.). 
The APOM has instituted an annual award to incentivize and promote the creativity and imagination of Portuguese museologists, all with a view to improving the quality of museums in Portugal and giving visibility to the work carried out in this domain. Given this tendency for epistemological categorization, it makes sense to try to understand the range of thematic areas covered by these museums and study how this museological development occurs. Through this territorial analysis, this research aims to map out the panorama of museums in Portugal, focusing on contributions that could be used for the practical construction of a museography of design.

\subsection{Criteria for sample selection}

In order to proceed to the selection of museums, it was necessary to define criteria to be used for analysis during the visit. These were based on the criteria used by the RPM, APOM and a choice of different thematic museum to ensure heterogeneity. We were particularly interested in understanding the criteria used by the APOM in awarding its annual prizes to Portuguese museums. Five of the 23 categories were selected: Best Portuguese Museum; Best Exhibition; Best Catalogue; Best Site, and Best Museographic Work (APOM, undated). The criteria adopted by the APOM to distinguish the awardwinners and runners up should be coherent and respect the ICOM statutes, which are essential for the organization and functioning of the institution, specifying its aims, mission and structural organization.

The museum visits will aim to acquire an understanding of the different exhibition systems in operation, by analysing what is displayed and how, thereby revealing the underlying epistemological intention.

As regards the second assessment criterion, the inclusion of diverse thematic museums, we believe that this is very important given the great diversity in Portugal. We do not want to restrict ourselves to the prize-winning museums, running the risk of leaving out other important units. This thematic diversity is justified by the search for and analysis of the different themes covered. Such a broad museological contextualization is vital as it provides a sounder and more complete epistemological basis for our mapping out of Portuguese museums. It will provide a more thorough background for the research to be carried out (with repercussions for funding), as it will enable us to understand different situations with regard to our proposal to produce a new type of design mediation.

After surveying and characterizing the various Portuguese museums and their display systems, we should be in a position to understand what is needed for a museography of design. It will also help us understand the extent to which design is inserted into the process, contributing to the creation of new technologically mediated models of information transfer.

\subsection{Analysis of the museums}

The survey will take place using the methodology presented, and the strategic definition of the parameters to be investigated are manifested in an assessment sheet. A qualitative study will be carried out involving interviews, technical research (about the museographic forms used for the mediation of the objects and how they occur in physical and virtual space) and individual case studies, in order to reinforce and assess the results. This data should enable us to map out the museographic scenario in Portugal and identify the various epistemological approaches to exhibition that exist.

The exploratory qualitative research method was chosen for this analysis in order to assess perceptions and understandings concerning the general nature of museology, 
opening up the space for interpretation. This is inductive research, allowing us to develop concepts, ideas and understandings from patterns found in the data. For this purpose, a form will be created (Fig. 1) to enable the collection of epistemologically relevant data, thereby enabling direct interaction with the museological object.

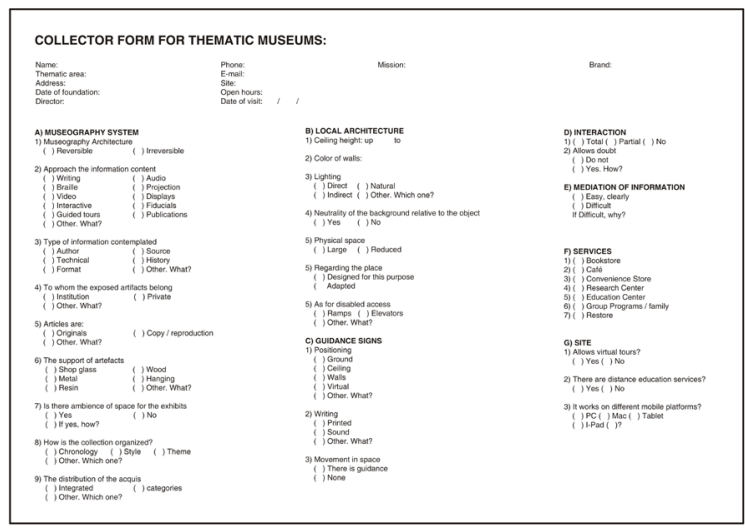

Figure 1.

Museographic assessment form

Some variables will be defined prior to data collection to enable concepts related to the object of study to be conceptually and technically checked. These include: 1) the characteristics of the museographic system found at the site (the approach used, type of information provided, organization and design of the space, distribution of the collection, reversibility of the museographic system); 2) the architecture (details of plan, lighting system, physical space, access for the disabled); 3) signposting (positioning, route, circulation in space); 4) interaction; 5) mediation if information; 6) services offered; 7) virtual access/ distance-training.

Bibliographic research will also be carried out in areas related to design, such as heritage and philosophy.

\section{Conclusion}

Many different types of museums have appeared in recent decades, and so the concept is very broad. This is intensified by the existence of various thematic areas, each with its own epistemology and, presumably, museography.

This mapping-out of the various exhibition systems should shed new light on museography in Portugal. Assuming that there are gaps still to be filled, we aim to explore museology from the perspective of design, understanding the activity of designer that develops museographic works through mediation and the use of particular strategies.

By choosing a small number of museums representative of a wide variety of themes (museological epistemology), this museographic analysis will seek to understand what is relevant for a museographic approach particular to design.

\section{References}


Available at: http://www.apom.pt/

[Accessed 21 January 2014].

Baptista, C. S. \& Sousa, M. J., 2011. Como fazer investigação, dissertações, teses e relatórios - Segundo Bolonha. $4^{\mathrm{a}}$ ed. Lisboa: Lidel - Edições Técnicas, Lda.

Choay, F., 1999. Alegoria do Património. Lisboa: Edições 70.

$\mathrm{cm}$-oeiras, 2013. cm-oeiras. [Online]

Available at: http://www.cm-oeiras.pt/municipio/Rellns/OutRelExt/Paginas/APOM.aspx

[Accessed 21 January 2014].

ICOM, 2010. icom.museum. [Online]

Available at: http://icom.museum/

[Accessed 5 january 2014].

IMC, 2013. Rede Portuguesa de Museus. [Online]

Available at: http://www.imc-ip.pt/

[Accessed 21 January 2014].

Kerckhove, D. d., 1998. Inteligência Conectiva. London: Kogan Page Limited.

Kraus, M. \& Pereira, P., 2008. Deutches Historisches Museum. [Online]

Available at: http://www.dhm.de/ausstellungen/neue-welten/pt/

[Accessed 5 January 2014].

Lisboa, U. d., 2010. Museu Nacional de História Natural e da Ciência. [Online]

Available at: http://www.mnhnc.ul.pt/

[Accessed 26 January 2014].

Mendes, J. A., 2013. Museus e Educação. 2ª ed. Coimbra: Imprensa da Universidade de Coimbra.

\section{Acknowledgements}

This work is funded by CAPES Scholarship - № 076213-0. CAPES Foundation, Ministry of Education of Brazil, Brasília - DF 70040-020, Brazil, and by FEDER through the Operational Competitiveness Programme - COMPETE - and by national funds through the Foundation for Science and Technology - FCT — in the scope of project PTDC/CPCDES/4754/2012 (FCOMP-01-0124-FEDER-028530).

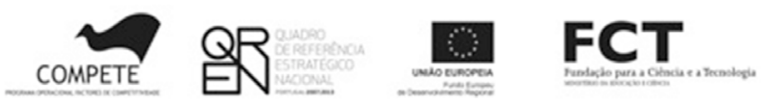

